\title{
C3-BIOECONOMY
}

Circular and Sustainable Bioeconomy

\section{Hacia la bioeconomía forestal en el Perú: cadena de valor, tendencias tecnológicas y necesidades de capital humano}

José Luis Solleiro Rebolledo ${ }^{1}$ y Myrsia Eliany Sánchez Goicochea ${ }^{2}$

Autor de Correspondencia: solleiro@unam.mx

\section{Resumen:}

En este artículo se analiza el desempeño de la industria forestal de Perú, desde la perspectiva de los elementos de su cadena de valor, las tendencias tecnológicas globales que impactan esta actividad y el capital humano disponible. La investigación se basa en la revisión de documentos oficiales, entrevistas a expertos y la realización de un taller de búsqueda de consenso. Se ha concluido que la industria forestal peruana no explota plenamente su potencial, principalmente por la desarticulación de la cadena, con debilidad en el eslabón de transformación; por la falta de incorporación de innovaciones debida a posturas conservadoras y falta de recursos; y la brecha entre la oferta y la demanda de recursos humanos en todos los niveles. El país necesita diseñar y ejecutar una nueva estrategia de desarrollo que asuma el concepto de gestión integral de cuencas como herramienta de desarrollo territorial, el fortalecimiento de las instituciones formadoras de recursos humanos y un plan de inversiones con visión de largo plazo. Las innovaciones serán indispensables para que esta industria se convierta en una bioeconomía redituable social y económicamente.

Palabras clave: Forestal, Perú, Bioeconomía, Cadena de valor, innovación

\section{Towards the forest bioeconomy in Peru: value chain, technological trends, and human capital needs}

\author{
José Luis Solleiro Rebolledo ${ }^{1}$ y Myrsia Eliany Sánchez Goicochea ${ }^{2}$
}

\section{Abstract:}

This paper deals with the analysis of the performance on Peru's forestry, from the perspective of the links of its value chain, global technology trends that are impacting this industry and the availability of human capital. This piece of research is based in the review of official documents, an interview conducted with experts and opinion leaders, and a consensus-building workshop with the participation of representatives of industry, government and academia. One main conclusion is that Peru does not take full advantage of its forest resources mainly because the value chain is not well articulated, with clear weaknesses in the transformation link. Due to very conservative attitudes and lack of resources, innovations are not adopted; and a there is a gap between supply and demand of human capital at all levels. Peru needs a new development strategy incorporating the concept of basin management for territorial development, strengthening of the education and training programs, and a sound investment plan with a long range approach. Adoptions of

1 Instituto de Ciencias Aplicadas y Tecnología, Universidad Nacional Autónoma de México, solleiro@unam.mx; ORCID 0000-0001-8969-0244

2 Facultad de Economía, Universidad Nacional Autónoma de México, mesg.225712@gmail.com; ORCID 00000002-8811-0700

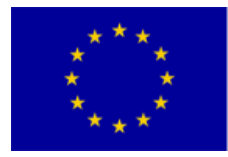

UNIÓN EUROPEA

PROYECTO COFINANCIADO POR EL FONDO EUROPEO DE DESARROLIO
(FEDER) Una manera de hacer Europa

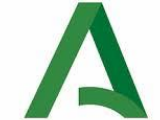

Junta de Andalucía
Andalucía

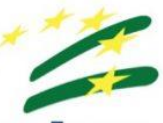

se mueve con Europa 
innovations along the value chain is critical for Peru to make the transition to a forest bioeconomy able to yield positive socioeconomic impacts.

Key Words: Forest, Peru, bioeconomy, value chain, innovation

\section{INTRODUCTION}

The concept of bioeconomy refers to the use of renewable resources from different sources - crops, forests, animals, and microorganisms - to produce food, materials, and energy, focused on sustainability. Sustainable forest-based production is an important subsector of the bioeconomy, and countries with abundant forest resources and technological capacities in relevant areas are those that have the best conditions to develop it and have favorable socioeconomic impacts.

Currently, the world forest area is 4,060 million hectares $131 \%$ of the total land area), of which $93 \%$ (3.75 billion ha) is made up of naturally regenerating forests and 7\% (290 million ha) of plantations. More than half of the world's forests (54\%) are found in just five countries: Russia, Brazil, Canada, the United States, and China (FAO, 2020); therefore, they are the main producers of forest products. Currently, the value of forest products in 2018 was USD 270 billion, representing an increase of $10 \%$ over the previous year and the production of these products registered the highest increase in the last 70 years.

In this context, Peru has 72 million 330 thousand hectares of forests, which represent $56.5 \%$ of the national territory. Of these, $98 \%$ corresponds to natural regeneration (71 million 241 thousand ha) and it has lost 1 million 719 thousand ha since 2015, because of deforestation (FAO, 2020). At the world level and in Latin America, Peru ranks at the ninth and second place with the largest forest area, respectively, and 33rd place in worldwide plantations (MINAGRI, 2016).

The forestry sector represents $0.8 \%$ of Peru's national GDP; however, in the rain-forest regions, the contribution to their economies is on average $12 \%$. In 2017 , the share of forestry GDP in the economies of Madre de Dios, Loreto, and Ucayali represented $16 \%, 11 \%$, and $10 \%$ respectively. These three regions contribute $43 \%$ of the forest GDP. Estimates from the General Direction for Research and Studies on Foreign Trade (DGIECE) suggest that the forestry sector generates around 180 
thousand jobs in wood extraction and transformation activities; this represented $1.1 \%$ of national employment in 2017 (MINCETUR, 2018).

Annually, Peru produces an average of 7.8 million of $\mathrm{m}^{3}$ of wood, of which only $9 \%$ corresponds to timber products. In 2019, the country produced 1.2 million of $\mathrm{m} 3$ of Roundwood, decreasing by $19 \%$ compared to the previous year; while sawn wood, laminated wood, and parquet grew by $29 \%, 23 \%$, and $88 \%$ respectively compared to 2018. According to PRODUCE (2006), there are 24 million hectares characterized as permanent production forests (BPP) and at least 10.5 million hectares suitable for reforestation (although native community areas are not included).

The value chain of the forestry sector in Peru is made up of three main links: forest management, transformation, distribution, and commercialization. In each of these ones, different activities are carried out. The chain begins with forestry and extraction activities, going through a primary transformation process, then secondary transformation and finally, the finished wood-based products are distributed and commercialized.

At a global level, there is consensus about the factors that will determine the development of forestry agribusiness: the maximization of the economic and social impacts of the value chain; the search for cleaner production processes; and the consolidation of the perspective of territorial development based on a competitive and sustainable agribusiness approach (Ludvig et al., 2019).

Inside the framework of these factors, current technological trends in the sector are related to great efforts and investments in innovation and human capital with specialized technical knowledge that responds to demand. It is widely acknowledged that new technologies open the way to the creation of new jobs and/or acquisition of new skills in existing ones, along the value chain.

This paper aims to identify, analyze, and characterize the forestry sector in Peru from the perspective of its value chain, global technological trends, and human capital required to realize the potential of Peru's forestry. 


\section{RESEARCH METHOD}

To meet paper's objective, a qualitative-analytical methodology was used. Secondary information was reviewed, mainly official reports3, articles, and foresight studies on this sector, and primary information was collected through the semi-structured interview technique and a consensus-building workshop with participation of experts from industry, government and academia. Qualitative research encompasses several approaches, but none provides numerical measures; such qualitative research is distinguished from the quantitative tradition in the way of collecting information, construction of observations, the modes assumed by the analysis, the procedures to obtain reliability, as well as in the elaboration of interpretations (Tarrés, 2015; King, et al., 2012).

Hence, different in-depth interviews were conducted with experts from the sector (national and international): consultants, forestry entrepreneurs, faculty, and government officials (see table 1). The zoom platform was used for videoconferences and the interviews focused on knowing the current state of forest production in Peru, its perspectives, transformation activities, and existing capacities, within the framework of a technological transformation accelerated by biotechnology, mechatronics, and information technologies. Additionally, as mentioned above, a workshop (an interactive online focus group) was held to validate information collected in the interviews and discuss the expected changes in technologies, employment, and strategies, as well as some policy recommendations for the development of the sector in Peru.

\footnotetext{
3 Public databases from SERFOR, the Ministry of Education and the Ministry of Labor, were used; similarly, current and relevant studies of the sector, such as "Cadenas de valor en el sector forestal en el Perú", "Cadena productiva de la madera", "La industria de la madera en el Perú", "Estudio de la oferta educativa y demanda laboral en el sector forestal a nivel nacional".
} 
Table 1: Interviews conducted.

\begin{tabular}{|c|c|}
\hline Interviewed & Institution \\
\hline Saul Monrreal & México \\
\hline Fernando Carrera & $\begin{array}{c}\text { Professor at the Tropical Agricultural Research and } \\
\text { Teaching Center (CATIE-Costa Rica) }\end{array}$ \\
\hline Evelyn Chavez & $\begin{array}{l}\text { Sustainable agribusiness specialist-CATIE-Native } \\
\text { Communities. }\end{array}$ \\
\hline Oscar Santamaria & $\begin{array}{c}\text { General Manager in Amazonía Justa SAC and } \\
\text { professor in CATIE. }\end{array}$ \\
\hline $\begin{array}{l}\text { Sonia González } \\
\text { Molina }\end{array}$ & Director of capacity building in SERFOR. \\
\hline Carolina Ramirez & $\begin{array}{l}\text { Director of Economic Studies and Agricultural } \\
\text { Information-MIDAGRI }\end{array}$ \\
\hline Enrique Toledo & General Manager in Reforesta Perú \\
\hline Olga Loyola & Operations Manager in Reforesta Perú \\
\hline Vaneza Caycho & General Manager in iFurniture \\
\hline Gustavo Tamariz & Operations General Manager in Bozovich \\
\hline $\begin{array}{l}\text { Gilberto } \\
\text { Dominguez }\end{array}$ & $\begin{array}{c}\text { Researcher at the National Intercultural University of } \\
\text { the Amazon }\end{array}$ \\
\hline Enrique Gonzales & $\begin{array}{l}\text { Vice-rector of the Forestry Faculty of National } \\
\text { Agrarian University La Molina (UNALM). }\end{array}$ \\
\hline $\begin{array}{l}\text { Tedi Pacheco } \\
\text { Gómez }\end{array}$ & $\begin{array}{c}\text { Dean of the forestry faculty of the National University } \\
\text { of the Peruvian Amazon (UNAP) }\end{array}$ \\
\hline Zoila Cruz & Professor of the Forestry Faculty of UNALM \\
\hline $\begin{array}{l}\text { Ethel Rubin de } \\
\text { Celis }\end{array}$ & Director of the Forestry Faculty of UNALM. \\
\hline Ingrid Casas & $\begin{array}{l}\text { Professor of the forestry faculty of the University of } \\
\text { Chachapoyas. }\end{array}$ \\
\hline Jessica Moscoso & Director of CITE Madera Lima. \\
\hline Darcy Laclotte & Director of CITE Mader Ucayaly. \\
\hline Oscar Parra & $\begin{array}{c}\text { Coordinator of the technical career of forestry of } \\
\text { IESTFFAA }\end{array}$ \\
\hline Alberto Apolinario & Coordinator of CEPTRO-Ancash. \\
\hline $\begin{array}{l}\text { Juan Carlos } \\
\text { Navarro }\end{array}$ & President of MCLCP-Ucayali. \\
\hline $\begin{array}{l}\text { Jesús Santiago } \\
\text { Díaz }\end{array}$ & Project Consultant for USAID \\
\hline Alonso Rizo Patron & $\begin{array}{c}\text { Project Consultant for USAID and - SERFOR - } \\
\text { Company }\end{array}$ \\
\hline Javier Arce & Project Consultant for GIZ \\
\hline
\end{tabular}

Source: Authors' elaboration. 


\section{RESULTS}

\subsection{Value chain of the forestry sector}

According to CEPAL (2014), a value chain comprises all the variety of activities that are required for a product or service to pass through the different stages of production, from its conception to its delivery to consumers and its final disposal after use (Kaplinsky, 2004). Based on the literature review (Rodríguez \& Kometter, 2012), CEPAL (2014), UNIQUE (2015), MTPE (2019) and USAID-SERFOR (2019), and the set of interviews with actors involved in the forest value chain in Peru, it has been identified that the value chain is made up of three main links: forest management, transformation (primary and secondary), and commercialization. These links include specific activities as shown in see Figure 1.

Figure 1: Value chain of the forestry sector in Peru.

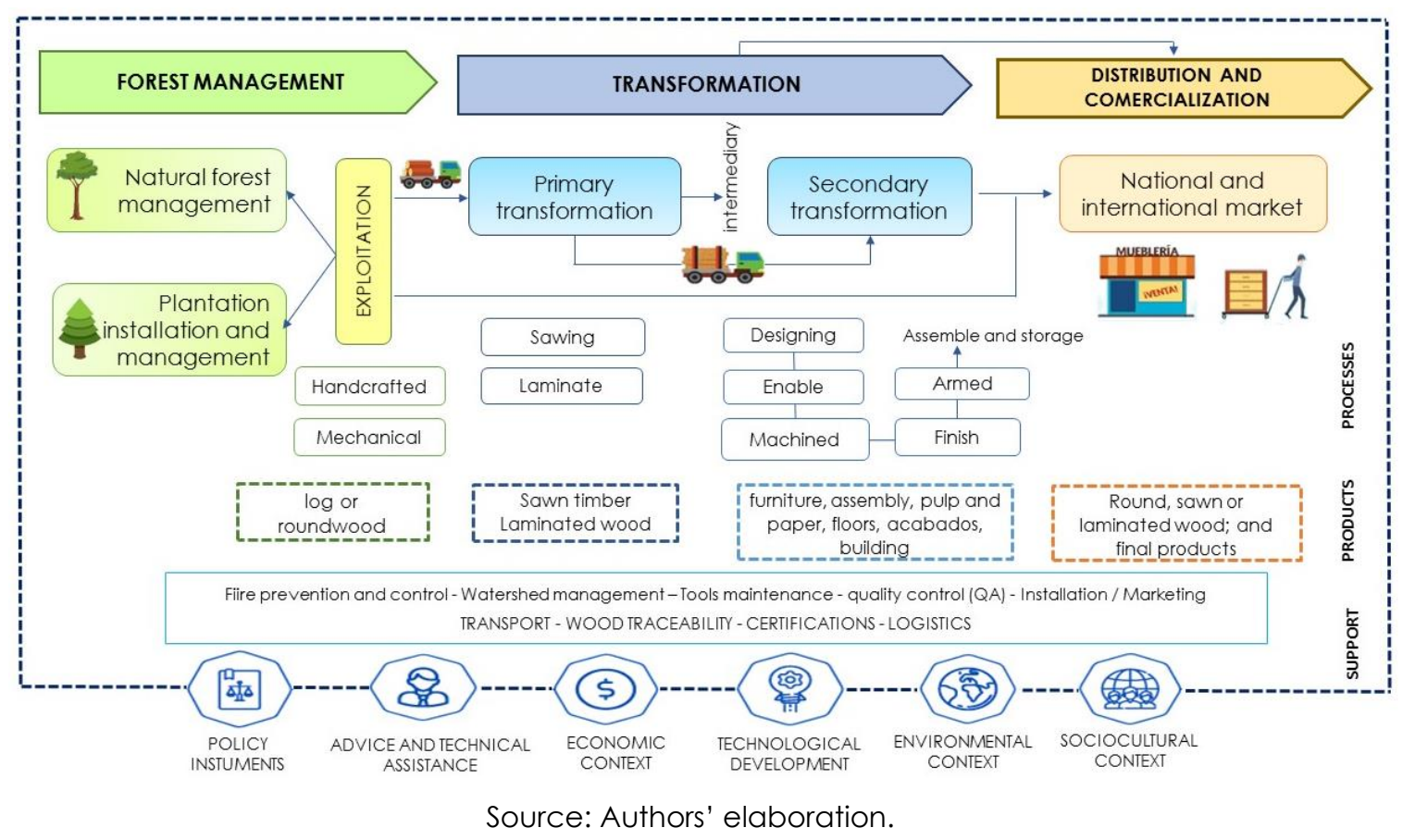

In the case of Peru, forest management, in addition to the use of natural forests, includes the installation and management of plantations, which in turn implies planning, production of seedlings in forest nurseries, installation, management, harvesting, and supervision. Forest management and utilization encompass planning, forest management, road construction, utilization execution, residual forest balance, and regeneration monitoring. 
Once the wood has been extracted from natural forest or plantations, Roundwood undergoes a first transformation, where it is sawn, edged, and blunted to obtain planks, boards, veneers, and other intermediate wood products. Afterward, the sawn or laminated wood goes through a second transformation, where products with higher added value are obtained such as floors (parquet, decking), domestic and office furniture, construction parts (doors and windows, among others), packaging material, paper, formwork, car bodies, shipyards, among others. And finally, marketing and distribution occur at two levels: inputs and finished products.

Similarly, based on FAO (2018), the actors along the value chain were identified. The forestry sector in Peru is made up of direct actors who intervene in the productive activity, most of them are private agents; and indirect actors who are related to processes of promotion, regulation, and support of forestry activity represented by a combination of private and public agents (see figure 2).

Figure 2: Actors in the value chain of the forestry sector in Peru.

\begin{tabular}{|c|c|c|c|c|c|}
\hline \multicolumn{3}{|c|}{ FOREST MANAGMENT } & \multicolumn{2}{|c|}{ TRANSFORMATION } & \multirow{2}{*}{$\begin{array}{l}\text { DISTRIBUTION AND } \\
\text { COMERCIALIZATION }\end{array}$} \\
\hline $\begin{array}{l}\text { Natural Forest } \\
\text { Managment }\end{array}$ & $\begin{array}{c}\text { Forest } \\
\text { plantations }\end{array}$ & Exploitation & $\begin{array}{c}\text { Primary } \\
\text { Transformation }\end{array}$ & $\begin{array}{c}\text { Secundary } \\
\text { Transformation }\end{array}$ & \\
\hline \multicolumn{5}{|c|}{ Ministry of Environment (MINAN) } & SUNAT-ADUANAS \\
\hline \multicolumn{5}{|c|}{ National Forest and Wildlife Service (SERFOR) / National Forest Chamber (CNF) / CONAFOR } & PROMPERÚ \\
\hline \multicolumn{3}{|c|}{ National Forest and Wildlife Management System } & \multicolumn{2}{|c|}{ Technological Institute of Production } & ADEX $>$ \\
\hline \multicolumn{3}{|c|}{ Universities that offer forestry education programs } & \multicolumn{2}{|c|}{ National Institute of Quality /Innovate Perú } & \\
\hline \multirow{2}{*}{\multicolumn{3}{|c|}{$\begin{array}{l}\text { Non-university Higher Technological Education (IEST) } \\
\text { Forest Resources Administration }\end{array}$}} & \multicolumn{2}{|c|}{ Ministry of Production (PRODUCE) } & \\
\hline & & & \multicolumn{2}{|c|}{ Universities and Institutes } & olesalers / retallers \\
\hline \multicolumn{5}{|c|}{ Productive technician (CEPTRO) - Educational Technological Innovation (CITES) - Competency certifiers } & Exporting companies \\
\hline \multirow{2}{*}{$\begin{array}{c}\text { Forest } \\
\text { management } \\
\text { companies }\end{array}$} & $\begin{array}{l}\text { AGROPERÚ } \\
\text { (Financingl }\end{array}$ & $\begin{array}{l}\text { Forest Resources and } \\
\text { Wildlife Supervision }\end{array}$ & \multirow{5}{*}{$\begin{array}{l}\text {-Ucayali Timber Export } \\
\text { Consortium } \\
\text {-Company dedicated } \\
\text { to laminate } \\
\text {-Sawmill companies. } \\
\text {-Triplayeras } \\
\text {-Construction timber. } \\
\text {-Forest Warehouses. }\end{array}$} & \multirow{5}{*}{$\begin{array}{l}\text {-Wood Industry Asociations } \\
\text {-Regional Chamber of } \\
\text { Second Transformation. } \\
\text {-Association of loggers } \\
\text { and carpenters. } \\
\text {-Lumber craftsmen. } \\
\text {-Furniture Manufacturers } \\
\text { Association. } \\
\text {-Flooring producers. }\end{array}$} & Intermediary \\
\hline & & & & & \multirow{2}{*}{$\begin{array}{l}\text { Association of timber } \\
\text { transporters }\end{array}$} \\
\hline \multirow[t]{3}{*}{ AIDESEP } & $\begin{array}{l}\text { Forestry } \\
\text { companies }\end{array}$ & $\begin{array}{l}\text { Concessionaires } \\
\text { Native communities }\end{array}$ & & & \\
\hline & & Small producers & & & Small merchants \\
\hline & \multicolumn{2}{|c|}{ Association of reforesters and extractors } & & & \\
\hline \multirow{2}{*}{\multicolumn{3}{|c|}{ Companies with certification in forest management/ FSC Perú }} & Wooc & mportes & \\
\hline & & & \multicolumn{3}{|c|}{ Companies with certification in wo od custody } \\
\hline \multicolumn{6}{|c|}{ Facilitators - Machinery and equipment suppliers - Service providers - Financial providers - ONG } \\
\hline
\end{tabular}

Source: Authors' elaboration.

Figure 2 illustrates the complexity of this industry. Private and public institutions coexist but there is little articulation mainly because private sector is 
integrated by many small producers and firms with low capacities. A small number of large, certified firms have competitive strategies. Government is in charge of designing policies and regulations, but implementation is rather low because of the lack of resources.

For that reason, there is a high level of consensus among the specialists interviewed that Peru does not use its forest resources sufficiently and adequately. Many very small farms have little access to technologies and qualified personnel, and their operation is not very efficient. Therefore, specialists agree that a change in the production model is necessary, adopting a territorial development approach that contemplates the integral and sustainable use of the forest, as well as the mechanisms to improve the distribution of benefits. This requires new knowledge on socio-economic, regulatory, and business issues.

Another finding was that forest plantations have little presence in the market, although they have a high potential to generate profitable businesses. The design and operation of plantations require new professional profiles since knowledge about plant biotechnology, nursery management, plant nutrition, and integrated pest management are needed. Plantation investors have difficulties to obtaining financing and government support since decision-makers seek effects in the short term.

Another important result is related to support activities for forest management and wood transformation. In the case of forestry support, experts highlight that, in order to overcome current knowledge and skills gaps, it is important to promote training and specialization in:

- water management and forest eco-hydrology.

- comprehensive risk management and prevention of forest fires through the formation of chains of command, brigades, and forest firefighters to leave reactive behavior on fires and other events and build capacities to base security on planning and prevention.

- maintenance of forestry equipment, design, and manufacture of tools and devices, and spare parts. 
- $\quad$ use of information technologies and data processing.

- Three key positions are critical within forest use that need to be recognized and trained: 'materos' (local people who know in detail the forests and the species present), chainsaw operators, and 'cubicadores' (empirical technicians dedicated to quantification of wood volumes). These positions are generally empirical so, for their professionalization, technical schools need to work to standardize and strengthen those skills.

Similarly, in the transformation stage, it is necessary to strengthen capacities related to machinery maintenance, wood drying processes, metrology and quality management, risk prevention, and occupational safety. Modern machinery tends to use digital resources to automate and program it; thus, the profile of operators is evolving towards the use of digital skills.

An important deficiency in the secondary transformation refers to the design of wooden buildings and furniture. Currently, production is carried out in a very traditional way and only a few companies have developed digital capabilities that are increasingly important for competitiveness.

It is important to note that the latest Global Witness report (2019) based on data from OSINFOR estimated that at least $60 \%$ of the Peruvian wood supervised in the last 10 years had an illegal origin (MAAP,2021). Likewise, this coincides with the opinion of the experts consulted, in the sense that illegal exploitation is an element of distortion that generates unfair competition, loss of carbon and biodiversity, uncontrolled deforestation and deficiencies in the quality system, which detracts from the presence of products Peruvians in the markets. Given this, it is fundamental to improve and enforce the legal framework, to implement an accurate calculation of the Peruvian logging and the illegal trade index, and to promote better measures to identify and penalize illegal trade. As a complement, forestry companies should work to get their certification, which requires capacity building and investment, but it is a major step to participate in the global trade. 


\subsection{Macro trends in the forestry sector}

The forestry sector has traditionally been characterized by lacking great efforts and investments in innovation. The main sources of technological change have been equipment manufacturers, where more efficient machines are designed for cutting, handling, transporting, drying, and processing tasks. But beyond that, forest exploitation has been rather conservative, mainly due to cultural elements, deep-rooted traditions, scarcity of resources in small companies, lack of generational change, little investment, and little profitability.

Although the forest has been seen only as a source of timber resources, it is important to recognize that it also provides numerous "collateral" products, goods, and services such as firewood, wild fruits, mushrooms, biomass as an energy source, ecological tourism, inputs for chemical and pharmaceutical industry, among others. Environmental services like $\mathrm{CO}_{2}$ capture are relevant elements to be considered. Consequently, various initiatives have been identified internationally to enhance forest management, with the dual focus of profitability and sustainability as well as various technologies under development (Teischinger, 2010; Ludvig et al., 2019; Govermment of Canada, 2020) in the field of processing. A summary of the main technological trends that are relevant for the different links of the value chain is illustrated in Table 2.

Table 2: Main macro trends in forestry innovation.

\begin{tabular}{|c|c|}
\hline Link of the chain & Technological trend \\
\hline $\begin{array}{c}\text { Forest } \\
\text { management }\end{array}$ & $\begin{array}{l}\text { - Georeferencing using drones, LiDAR, sensors, and } \\
\text { other devices. } \\
\text { - Forests and territorial development. }\end{array}$ \\
\hline Forest plantations & $\begin{array}{l}\text { - Genetic improvement, plantations, and reforestation. } \\
\text { - Integrated pest management }\end{array}$ \\
\hline Exploitation & $\begin{array}{l}\text { - High-performance machinery. } \\
\text { - Molecular markers. }\end{array}$ \\
\hline $\begin{array}{l}\text { Primary } \\
\text { transformation }\end{array}$ & - Modeling and simulation for cutting optimization. \\
\hline $\begin{array}{l}\text { Secondary } \\
\text { transformation }\end{array}$ & $\begin{array}{l}\text { - Analysis of processes and management systems. } \\
\text { - Design and simulation: smart construction. } \\
\text { - Materials: additives, solvents, pharmaceuticals, } \\
\text { biofuels }\end{array}$ \\
\hline
\end{tabular}

Source: Authors' elaboration. 
The specialists highlight some important changes with likely impacts on production systems and labor demand. In forest management, elements such as the use of drones, sensors, systems, and other devices to map terrain, georeferencing species and detecting hot spots, as well as advances in biotechnological methods to identify species using molecular tools, improve varieties and develop strategies to combat pests, are setting trends at a global level. For that reason, they will be drivers of change in the planning and operation of forestry operations.

On the other hand, advances in the design and development of prototypes using different software and 3D printing devices, digitization, and automation of production processes are impacting transformation activities. Likewise, the use of technologies associated with Industry 4.0 as well as innovations in distribution and commercialization (artificial intelligence, loT and data science) generate changes in labor demands of the transformation segment in the forestry sector.

The tendency to take advantage of forest resources in an integral way requires professionals with a holistic vision, who know the approaches of interculturality, evaluation of socioeconomic factors, territorial development, and promotion of sustainability.

Productive operations and logistics are changing, requiring more and more specialized workers with knowledge of data management and control indicators, process management, forestry business planning, and marketing.

On the other hand, other important aspects in the sector that will impact labor demand are associated with the traceability of wood, optimization of processes to ensure yields, quality assurance, guarantee occupational health and safety, inventory rotation, and reduction of waste.

Finally, in recent years the Peruvian forestry sector has shown dynamic behavior, especially in the domestic market (Arce, 2021; Tamariz, 2021); thus, it is expected that this sector may continue to grow. The wealth of the country in 
terms of forested areas represents an underutilized potential that, if properly exploited, can represent an opportunity for territorial development and a good source of income.

\subsection{Human resources}

Human capital in the forestry sector plays a crucial role and requires certain specialized skills and knowledge. The characteristics of vocational and technical training must respond to the needs of companies and society. Regarding the training centers and institutes available for the Forestry sector in Peru, those described in table 3 have been identified.

Table 3: Synthesis of the forestry training offer in Peru.

\begin{tabular}{ccc}
\hline Education level & $N^{\circ}$ of Institutions & $\begin{array}{c}\text { Careers and } \\
\text { programs }\end{array}$ \\
\hline Universities-undergraduate & 20 & 10 \\
Universities-postgraduate & 9 & 9 \\
Non-university Higher Education & 9 & 2 \\
(IEST) & 177 & 6 or more \\
Productive technician (CETPRO) & 4 & 30 or more \\
Educational Technological & 10 & 11 \\
Innovation Centers (CITES) & 3 & 20 or more \\
Competency certifiers & Training and courses &
\end{tabular}

Source: Authors' elaboration with data from SUNEDU (2020), SINEACE (2020), ITP (2021), and official pages of institutions.

However, the entrepreneurs interviewed agree that the current profile of forestry professionals is very forest-oriented; therefore, they have little knowledge of the business, markets, the rational of plantations, and the wood industry. There are shortcomings in data management and analysis, forestry planning, evaluation of investment projects, marketing, genetic improvement, management and maintenance of forestry equipment and machinery, among other gaps. Due to salary distortions and organizational problems, technicians have been carrying out activities of laborers. This deteriorates the labor market.

On the other hand, the interviewees also agree that, beyond technical deficiencies, the development of soft skills (communication, leadership, teamwork, and language skills, among others) by professionals linked to the 
forestry sector is very weak. Therefore, it is urgent to strengthen these competencies to enhance the professional growth of workers and thus achieve better results at the firm level. Likewise, they consider that it is necessary to strengthen the subject of entrepreneurial training and train professionals with a long-term strategic business vision, able to design programs and investments in research, development, and innovation that are critical for industry's modernization, sustainability and competitiveness.

Gaps are also identified in the training of workers since the possibilities of training outside the workplace are more difficult due to the lack of flexibility of the companies (they do not permit their employees to access to training courses during working hours and are not keen to invest in human capital qualification); training remains with an on-the -job approach at the level of the operator and it is therefore important to strengthen qualifications including training for middle managers and professionals. Most employers are not committed to training their workers because they think that training their staff more is a risk (migration of talent); consequently, human capital management is weak. Additionally, it is worth mentioning that there is no job stability and salaries are not competitive. Consequently, human capital management is not used as a tool to boost competitiveness.

The problem of education and training is critical since schools, institutes, and universities have few resources and little budget. Thus, there are no adequate facilities (laboratories and workshops), a budget for field practices and research projects. In these circumstances, improvisation, and various mechanisms of informal cooperation between institutions must be resorted to. Policymakers in education and forestry development have not been sufficiently sensitive to this situation. Companies demand better skills in the areas previously presented, but they do not have a proactive attitude to strengthen academic institutions. As mentioned before, a contradictory situation is observed because firms' managers are reluctant to invest in training because they consider that the trained employee is going to resign to get job with competitors. 


\section{DISCUSSION}

The forestry activity will evolve towards the use of new technologies that will determine and drive the change in demand of human capital. The new technologies point towards main axes such as digitization of machinery and processes; comprehensive management of basins with a territorial development approach; genetic improvement of species; comprehensive risk management; optimization of operations; adding value through design and manufacturing improvements; market intelligence to capture higher value niches; and quality assurance in wood and wood products.

It is often argued that small producers handle more artisanal processes and that it will be difficult for them to participate in these changes. However, it is not advisable to ignore what is happening in this segment of industry, especially if the objective is to promote a competitive forestry agribusiness that increases the benefits for the communities that live in the forests. The economic and social yields will be realized only if there are profitable activities and these depend to a large extent on the response that is given to this new technological, regulatory, and market environment. For this reason, the country must be prepared, and this must be done now, since there is full agreement that the changes are already taking place, they are not theoretical.

Also, there is a coincidence with the SERFOR-GIZ study (2016), in that the supply of forestry education and training does not currently respond to labor demand. For this reason, a restructuring of the curricular networks is necessary where there is a greater balance between forest management, plantations, and the wood industry; that training should include different approaches to ensure interdisciplinary education and capacity building. Courses should also include contents on forestry planning and marketing, use of technologies, use of specialized software, equipment maintenance, business management, work ethics. Dual education systems should be analyzed and implemented to allow theoretical knowledge to be landed with practice in different companies. Teachers require training to update their knowledge and adapt themselves to scientific-technological trends and advances, because they are the corner 
stone of transformation. To implement these changes greater resources and new incentives are required.

Higher education institutions must be more flexible and adapt themeselves more quickly to changes imposed by labor demand, as there is evidence that a change in the career curriculum usually takes years. Likewise, the importance of forming soft skills such as oral and written communication skills, analytical capacity, teamwork, leadership, work ethic, and creativity, among others, is underlined. These competencies are critical to improving job performance, as well as facilitating job mobility.

On the other hand, the certifications of forests, plantations, processes, and procedures, together with issues such as traceability, quality audits, and sustainability, acquire increasing relevance. Dealing with these issues requires professionalization and ongoing training. In this sense, forestry entrepreneurs must be sensitized about the importance of investing in continuous training and scholarship programs for their workers; currently, they consider it as an expense.

The national policies on forestry must be strategically designed with a longterm vision and have more effective promotion instruments to foster competitiveness and sustainability of the forestry industry. The forest industry must be promoted and strengthened thereby that companies can grow and develop, generate labor demand that in turn generates forest supply. Promotion must come from the identification of the drivers of competitiveness and proactivity accompanied by political will; it is necessary to invest, that the policies translate into adequate budgets for programs, and that these are executed.

In this sense, it is pertinent to mention that one of the important advances of SERFOR has been the approval of the Capacity Development Plan for Forest and Wildlife Management (2021-2025). This plan is expected to strengthen the capacities of the actors in the forestry sector from various fronts such as continuous training programs, capacity building programs, interactive learning groups, awareness programs, and training of trainers. These policies require appropriate budgets to become reality. 


\section{CONCLUSIONS}

The use of forest resources in Peru requires the full application of the existing regulatory framework and the design of public policies aiming at more efficient exploitation, profitability, and sustainability of the resource. Only in this way the forest can be converted into a bioeconomy that encourages territorial development. Observing the trends in other neighboring countries, probably forest plantations will gain importance, which will cause an increase in the demand for professionals and technicians related to this type of production.

Peru has an underutilized forest area, which makes it waste a source of wealth and a valuable instrument of territorial development. The bioeconomy approach along with the basin development approach can bring many answers to current problems.

\section{REFERENCES}

ARCE, J. (2021). Dynamics and capacities of the Peruvian forestry sector. (J. L. Solleiro, Interviewer).

CEPAL. (2014). Strengthening value chains as an instrument of industrial policy. Methodology and experience of ECLAC in Central America. Santiago de Chile: United Nations.

FAO. (2020). Global Forest Resources Assessment. Recovered from: https://fradata.fao.org/PER/fra2020/home/

FAO. (2018). The wood industry in Peru. Lima: FAO. Recovered from: http://www.fao.org/3/18335ES/i8335es.pdf

Govermment of Canada (2020). Forest pest management. Recovered from: https://www.nrcan.gc.ca/our-natural-resources/forests-forestry/wildlandfires-insects-disturban/forest-pest-management/13361

ITP. (2021). Red CITE. Recovered from: https://www.itp.gob.pe/nuestros-cite/

KAPLINSKY, R. (2004). Spreading the gains from globalization: What can be learned from value-chain Analysis?. Journal of Development Studies, $47(2), 74-115$. 
KING, G., KEOHANE, R., \& VERBA, S. (2012). The design of social research. The scientific inference of qualitative studies. Madrid: Editorial Alliance.

LUDVIG, A., ZIVOJINOVIC, I., \& AND HUJALA, T. (2019). Social Innovation as a Prospect for the Forest Bioeconomy: Selected Examples from Europe. Forests, 10, 878. doi:10.3390/f10100878.

MAAP. (2021). MAAP No. 139: ILLEGAL LOGGING IN THE PERUVIAN AMAZON - A NEW FLAGSHIP CASE. Recovered from: https://maaproject.org/2021/talailegal-peru-wtf/

MINAGRI. (2016). Production evolution of the forestry sector. Lima: General Directorate of Agrarian Policies.

MINCETUR. (2018). Commercial Report of Wood Products. Lima: Directorate General for Research and Studies on Foreign Trade. Recovered from: https://www.mincetur.gob.pe/wpcontent/uploads/documentos/comer cio_exterior/estadisticas_y_publicaciones/estadisticas/exportaciones/Re porte Comercial Productos Forestales.pdf

MTPE. (2019). Wood production chain: Frequent occupations and training offer at the national level. LIMA: MTPE. Recovered from: https://cdn.www.gob.pe/uploads/document/file/469920/Estudio de la Cadena Productiva de la Madera.pdf

PRODUCE. (2006). Strategic guidelines to promote forestry development in Peru. Lima.

RODRÍGUEZ, A., \& KOMETTER, R. (2012). Diagnosis of the Valve Chain of the Timber Forest Sector in the Ucayali Region. Lima: ILO.

SERFOR-GIZ. (2016). Study of the educational supply and labor demand in the forestry sector at the national level. Lima: SERFOR.

SINEACE (2020). List of authorized labor skills certification centers. Recovered from:

https://cdn.www.gob.pe/uploads/document/file/1472945/Listado\%20de 
\%20Centros\%20de\%20Certificaci\%C3\%B3n\%20de\%20Competencias\%20L aborales\%20Autorizados.pdf

SUNEDU. (2020). University Information System. Recovered from:

https://www.tuni.pe/

TAMARIZ, G. (2021). Dynamics and capacities of the Peruvian forestry sector. (M. Sánchez, Interviewer).

TARRÉS, M. (2015). Observe, listen and understand about the qualitative tradition in social research. México: The College of Mexico.

TEISCHINGER, A. (2010). The development of wood technology and technology developments in the wood industries - from history to future. European Journal of Wood and Wood Products, doi: 10.1007/s00107-010-0458-2

UNIQUE. (2015).Value chains in the Peruvian forest sector. Freiburg: UNIQUE. Recovered from: https://www.uniquelanduse.de/images/publications/vereinheitlicht/Cadenas de valor en el sector forestal del Peru.pdf

USAID-SERFOR (2019). Timber forest products. Explanatory guide for your identification. Lima. National Library of Peru. 